\title{
Dialektika Komunikasi pada Debat Pilpres 2019 dalam Perspektif Al-Qur'an
}

\author{
Wahab Nur Kadri \\ Program Magister Komunikasi Penyiaran Islam \\ Fakultas Dakwah UIN Syarif Hidayatullah Jakarta, Indonesia \\ wahabg7anakpulau@gmail.com
}

\begin{abstract}
Abstrak
Pada artikel ini berusaha untuk memahami makna Debat Capres 2019 yang terkandung dalam Al-Qur'an mengenai ayat-ayat Jadal melalui perspektif Dialektika Komunikasi juga dengan menelusuri pendekatan historis dan filosofis. Pembahasan ini mengantarkan penulis untuk memahami ilmu komunikasi dan Al-Qur'an dengan kisah dan sejarah di dalamnya khususnya dalam pembahasan : tentang jadal yang muncul disebabkan "pesan" yang turun setelah ada peristiwa seorang perempuan saliha bernama Khaulah binti Tsa'labah; tentang Al-Qur'an menggambarkan dirinya sendiri dalam kaitan dengan dialektika konsep Jadal melalui bentuk komunikasi (petunjuk dan wahyu) yang disampaikan kepada Rasul dan manusia di muka bumi; tengang umat Islam menjaga AlQur'an dari tradisi lisan yang ma'ruf menuju tradisi tulisan (para tabi'in, ulama dan pemikir Islam dan sebagainya) dalam menganalisis Jadal, di mana tradisi klasik tak akan pernah lenyap justru sebagai bingkai bagi pemikiran tentang Jadal berikutnya; tentang bentuk Jadal dalam Al-Qur'an perlu terus dikaji bahkan ditransmisikan dan ditransformasikan dalam konteks kini dan masa depan, seperti pada kontestasi Debat Capres, Pilgub, Pilkada, bahkan dalam wacana-wacana sosial, budaya, ideologi, dan agama (Islam). Melalui metode studi literatur dengan analisis tematik pemahaman Jadal dalam Al-Qur'an dapat dianalisis secara komprehensif dan objektif. Implikasinya, sebagai bagian dari ilmu komunikasi dalam bingkai Al-Qur'an, pemahaman Jadal memiliki signifikansi yang kuat karena dapat mencerahkan wawasan manusia menuju akhlakul karimah.
\end{abstract}

Kata Kunci: Konsep, Jadal, Perspektif, Al-Qur'an

\begin{abstract}
The 2019 Presidential Debate contained in the Qur'an about the Jadal verses through the Dialectic Communication perspective also by studying more deeply and philosophically. This discussion leads the author to discuss the science of communication and the Qur'an with stories and history in a special discussion: about the schedule that arises due to the "message" that comes after there is news of a saliha woman opened by Khaulah bint Tsa'labah; about the Qur'an quoting itself in discussions with the dialectic of the Jadal concept through forms of communication (guidance and revelation) conveyed to the Apostles and humans on earth; The Muslim Ummah needs the Qur'an from an oral tradition that is moving towards the written tradition (the tabi'in, Islamic scholars and thinkers and so on) in analyzing Jadal, where the classical tradition would never be expected. Next schedule; about the form of Jadal in the Al-Qur'an needs to be reviewed transmitted and transformed
\end{abstract}


in the present and future context, such as in the contestation of the Presidential Debate, Pilgub, Pilkada, even in social, cultural, ideological, and religious (Islamic) discourses. Through literature study methods with thematic analysis understanding Jadal in the Qur'an can be analyzed in a complete and objective manner. The implication, as part of the science of communication in the frame of the Qur'an, Jadal understanding has a strong significance because it can enlighten human insight into morality morals.

Keywords: Concept, Jadal, Perspective of Al-Qur'an

\section{Pendahuluan}

Perilaku komunikasi melalui "perang verbal" yang disebut debat isunya memang tepat diangkat pada awal tahun 2019 lalu bahkan sampai kini. Pemilu Capres-Cawapres antara Jokowi - Ma'ruf Amin dan Prabowo - Sandiaga Uno tampaknya tak berwarna tanpa arena adu opini dari kedua kandidat ini. Para pemilik media dan pesohor bangsa ini dengan dahsyat memfasilitasi dan mengakomodasi debat bagi ratusan juta pasang mata rakyat. Adu opini memang hanya sebagai alat politik, panggung teatrikal virtual atas dunia nyata, yang semua pelaku politiknya, baik tinggi maupun rendah, membentuk semacam "demokrasi katodik": ingin terus bisa dilihat mata, invansif, dan sangat obsesif atas perilaku manusia, mengaduk-aduk kebenaran politik, dan mengubah demokrasi yang semula bersifat partisipatoris terbuka menjadi program perangkat lunak yang semata ditujukan sebagai hiburan dan kontrol atas semua pemirsanya. Berbagai gaya dimainkan, berbagai komunikasi diluncurkan, dan berbagaia emosi diluaapkan. Inilah aksi debat. Seperti hail penelitian Novita Damayanti (2019) yang mendeskripsikan bagaimana seorang Jokowi menunjukan emotive styles-nya dalam melibas lawannya, Prabowo-Sandiaga Uno di seluruh media yang meliputnya. ${ }^{1}$

Dalam perpektif Komunikasi, Al-Qur'an itu berisi kalimat-kalimat verbal yang sarat makna, bermuatan kalimat petunjuk dan hidayah bagi seluruh ummat manusia dan tak dapat dipungkiri telah berhasil mengintegrasikan berbagai aspek pluralitas bagi umat manusia . Karena itu, logis bila ditemui begitu banyak proses mufasir Al-Qur'an dari masa ke masa dalam upaya mengungkap makna-makna, sistem, metode, dan implikasi debat yang termuat dalam Al-Qur'an sebagai pedoman perilaku, pikiran, dan keyakinan manusia terbesar dari Allah Swt. Selanjutnya, makna Al-Qur'an ditransmisikan oleh para pendakwah secara luas dan masif sepanjang zaman.

Dalam bahasa Indonesia, Jadal dapat dipadankan dengan debat. Menurut perspektif komunikasi, McLeod dan Chafee (1972) mengartikan debat sebagai pola percakapan dalam kelompok kecil, tetapi dalam skala yang luas karena diliput media massa dan melalui struktur ekspresi popular publik untuk meraih faksi opini dan aliansi sosial. ${ }^{2}$ Namun, pengertian sebenarnya yang mengarah pada pencapaian pemahaman-kesepakatan dan akurasi-kongruensi persepsi tereduksi oleh luapan emosi-ekspresi sebagai titik sentral perdebatan. ${ }^{3}$

Debat dalam perspektif Al-Qur'an diposisikan secara jelas dalam tiga tema, seperti : Tafsir Al-Qur'an, Kemukzizatan Al-Qur'an, dan Kisah-kisah dalam Al-Qur'an. Khususnya

\footnotetext{
${ }^{1}$ Novita Damayanti, Gaya Komunikasi Jokowi pada Debat Politik Pilpres 2019, Wacana Jurnal Ilmiah Ilmu Komunikasi, Vol. 14, No . 2 , 2015, 155.

2 McLeod dan Chafee, Handbook of Theories Communication, (London : Routledge. 1972)

${ }^{3}$ Depdikbud, Kamus Besar Bahasa Indonesia, edisi kedua Cet.III, 214.
} 
dalam ilmu Tafsir Al-Qur'an, seperti yang Najmuddin at-Tufi wafat pada $715 \mathrm{H}$, seorang Ulama' Mutaakhkhirin yang menulis secara khusus tentang debat ini. Najmuddin at Thufi memang hidup di tengah pergolakan politik yang sangat ekstrem di negaranya yang dipimpin oleh para amir yang memiliki pendirian yang sangat berbeda, sehingga menjadikan antara mereka seringkali saling berselisih dan menjatuhkan. ${ }^{4}$ Begitu pula yang terjadi pada zaman Nabi Muhammad saw saat menghadapi orang-orang Arab yang memiliki karakter yang kejam dan keras, di mana bila Rasulullah menyampaikan wahyunya tak pernah luput dari serangan, verbal maupun fisik dari bangsa Arab.

Secara etimologis, istilah Jadal berasal dari al-Jadlu (kokoh), al-Jadalatu (bumi atau tanah), al-Mijladu (istana),dan sebagainya. Semuanya bermakna kuat (al-quwwah), tercegah (imtina'), kokoh (al-syad), dan mematenkan (al-ihkam). Pengertian ini memiliki perumpamaan bahwa kedua belah pihak yang terlibat dalam suatu perdebatan (jadal) saling memperkokoh konstruksi opini atau argumentasi masing-masing, melalui upaya untuk mengalahkan lawannya untuk memenangkan opini atau argumentasi mereka. ${ }^{5}$ Dari rumusan definisi-definisi tersebut dapat disusun kaidah-kaidah debat, berikut ini : Hendaknya dengan jalan yang dapat diterima atau terpuji (dialektis), diniatkan untuk mendapat dalil argumen yang lebih kuat, untuk menunjukkan aliran atau mazhab serta kebenarannya. ${ }^{6}$

Istilah lain dari Jadal yaitu al Munazharah, al Muhawarah, al Munaqasyah, dan al Mubahatsah. Istilah-istilah tersebut dapat dipandang sepadan, sebab pada dasarnya mengacu pada tujuan yang sama yakni untuk menjelaskan suatu permasalahan. ${ }^{7}$ Disamping itu Allah juga memperbolehkan ber-munazarah (berdiskusi) dengan ahli kitab dengan cara yang baik dalam firman-Nya Dan janganlah kamu berdebat dengan ahli kitab, melainkan dengan cara yang paling baik" (al-Ankabut: 46). Sedangkan, muhawrah, munaqasyah, dan mubahatsah sesungguhnya mengacu pada pembicaraan di mana di dalamnya mengacu pada dialektika dan dialog dengan sopan yang bertujuan hampir sama saja dengan Jadal. ${ }^{8}$

Dengan perspektif dialektika komunikasi dalam bingkai Al-Qur'an, para pihak yang terlibat dalam jadal memang seyogyanya tidak harus saling membenci demi mencapai mutual understanding dan konsensus yang seimbang, walaupun pada dasarnya sulit menghidari suasana saling bermusuhan. Sebab, sebagian dari watak dasar manusia adalah memang suka membantah atau berbantah-bantahan, bahkan Tuhannya pun dibantah, dalam Q.S al Kahfi (18) ayat 54.

\section{Kerangka Teoretis}

\section{Tinjauan Pustaka}

Artikel ini didasarkan pada tinjauan penelitian dari Ahmad Khoirul Anam, Rumba Triana, Aceng Zakaria (2019) yang mendeskripsikan mengeksplorasi ayat-ayat Al-Qur'an dalam menjelaskan dan memahami tentang debat (jadal) melalui metode deskriptif dengan pendekatan studi literatur. Hasilnya bahwa debat pun terdapat dalam Al-Qur'an dan hadis,

\footnotetext{
${ }^{4}$ Khadar M Yusuf. Studi Alquran. (Jakarta: 2009), 4.

${ }^{5}$ Khadar M Yusuf. Studi Al-Qur'an, 4.

6 Zahir 'Awad al-Alamaiy Manahij al-Jadal fi al-Qur'an al-Karim, (t.tp.,t.th.,) 20.

7 Al-Raghib al-Isfahani, Mu'jam Mufradit al-Fadz al-Qur'an, (Beirut: Dar al-Fikr, t.th)

${ }^{8}$ Zahir 'Awad al-Alamaiy Manahij al-Jadal fi al-qur'an al-Karim, (t.tp.,t.th.). 25.
} 
sebagai bentuk "adu argumentasi" untuk mencari kebenaran yang hakiki dan bentuk perlawanan pada serangan kaum kafir pada Islam.9

Selain itu, artikel ini mengangkat hasil penelitian Ni Luh Arisma Mutiara, El Chris Natalia (2019) yang menyoroti tentang debat sebagai komunikasi publik pada komunikasi presiden pada masalah lingkungan dalam Pilpres 2019. Melalui perspektif Public Communication Theory, Environmental Communication, dan metode semiotika Roland Barthes, penelitian menemukan bahwa makna pesan debat memuat esensi budaya dan hubungan dengan media publik, kebijakan, dan isiu-isu lingkungan. ${ }^{10}$

Penelitian dari Sun Choirol Ummah tentang dialektika komunikasi yang menjelaskan tentang keberadaan agama di negara sekuler dianggap tidak memiliki pengaruh sama sekali terhadap dinamika Negara melalui pendekatan Teori Rasio Komunikatif, Etika Diskursus, dan Demokrasi deliberatifnya Habermas. Hasilnya menjelaskan bahwa dialektika antar warga negara sekuler dalam masyarakat post-sekuler dapat saling belajar secara demokratis, jika agama mampu mentransformasi diri dari agama mitis (religious-metaphysical) ke agama rasional (religiouspost-metafisik). ${ }^{11}$

\section{Perspektif Historis dan Filosofis Perpektif Historis.}

Secara historis Jadal memiliki arti pertentangan atau perselisihan atau perbedaan pendapat yang muncul bersamaan dengan hadirnya manusia di alam semesta ini. Menurut perspektif Al-Qur'an, jadal sudah ada jauh sebelum manusia pertama, Nabi Adam as diciptakan dan dilempar ke dunia yang ditandai peristiwa jadal yang dilakukan antara malaikat dengan Allah Swt saat mengungkpkan untuk menciptakan khalifah di bumi. Begitu pula, jadal yang dilakukan Iblis berupa penolakan ketika diperintah Allah Swt untuk bersujud kepada Nabi Adam as. Peristiwa tersebut bermakna bahwa jadal merupakan sifat dasar (given) yang melekat pada diri manusia sekaligus sebagai dinamika dalam kehidupan manusia. ${ }^{12}$

Riwayat peristiwa debat bisa ditelusuri dari masa Khalifah Umar bin Khaththab yang baru saja keluar dari masjid bersama Al-Jarud Al- Abdi yang tiba-tiba digugat oleh seorang perempuan berani, Khaulah binti Tsa'labah, istri Aus bin Shamit yang suaranya didengar Allah dari tujuh petala langit dengan gelar "Perempuan Pendebat/Penggugat". Sehingga, sang Khalifah tak bisa mengelak dari "perkataannya". Allah mengabadikan gugatannya dalam empat ayat pertama QS Al-Mujadilah ayat $58 .{ }^{13}$ Begitu pula, istilah debat muncul dari riwayat adanya seorang gadis yang mendebat ibunya saat diperintahkan untuk mencampur air susu yang akan dijualnya dengan air dalam HR Abu Dawud. ${ }^{14}$

Adapun sebab-sebab perkembangan masalah jadal di kalangan Muslimin dapat diidentifikasi dalam berberapa peristiwa sebagai berikut: Pertama, adanya ekspansi wilayah

\footnotetext{
9 Ahmad Khoirul Anam, Rumba Triana, Aceng Zakaria, “Debat dalam Perpektif Al-Qur'an : Studi Tematik Ayat-ayat tentang Debat", ProsA IAT: Prosiding Al Hidayah Ilmu Al-Quran dan Tafsir, Vol.1, No.1, 2019

${ }^{10}$ Ni Luh Arisma Mutiara, "El Chris Natalia, Pemaknaaan Pesan Komunikasi Publik dalam Debat Calon Presiden 2019", Jurnal InterAct, Vol. 8, No. 2, 2019

${ }^{11}$ Sun Choirol Ummah, "Dialektika Agama dan negara dalam Karya Jurgen Habermas", Jurnal Humanika, Vol. 16, Nomor 1, September 2016

${ }^{12}$ Jalaluddin Al-Suyuthi. Samudera 'Ulūmu al-Qur'ān. (Surabaya: Bina Ilmu Offset., 2008)

${ }^{13}$ Jalaluddin Al-Suyuthi. Samudera 'Ulūmu al-Qur'ān.

${ }^{14}$ Manna' Khalil al-Qaththan, Mabdhitsfi Uluum al-Qur'an (Beirut: Mansyurat at-Ashr, 1977), 298.
} 
Islam dan penetrasi para pemeluk agama lain ke dalam negara Islam; Kedua, perpindahan pemeluk agama non Islam ke agama Islam yang memunculkan pencampuran ajaran karena unsur budaya dan sosial yang dibawa sebelumnya; Ketiga, penggunaan rasionalitas yang dominan sebagai tuntutan zaman dalam pemecahan masalah sosial, politik, dan agama umat; Keempat, pesatnya perkembangan institusi-institusi hukum dan masyarakat yang memfasilitasi diskusi, dialog, dan sebagainya; Kelima, gencarnya dan tajamnya permusuhan yang dilakukan orang-orang Nasrani, Yahudi, Sekuler atau Barat, Atheis yang menyerang Islam; Terakhir, persoalan kajian atau pembahasan tentang tema-tema yang sulit dipahami (mutasyabihat karena masing-masing pihak melakukan pembenaran (taklid) sendiri-sendiri. ${ }^{15}$

Al-Qur'an menyebut kata Jadal sebanyak 29 kali dengan dalam berbagai jenisnya 29 kali yang pemuatannya tersebar pada 16 Surat dalam 27 ayat, berikut ini: Dalam Surah: alNisaa (4): 109 dan Huud (1l): 32 masing-masing 2 kali, al- Baqarah (2):197, al-Nisaa (4): 107, al-An'aam (6): 121,125, al- A'raf (7):71, al-Anfaal (8): 6, Huud (11):74, al-Ra'd (13): 13, al-Nahl (16): 111 dan 125, al-Kahfi (I8): 54 dan 56, al-Hajj (22): 3,8 dan 68, al-Ankabut (29):46, Luqmaa (31): 20.

\section{Perpektif Filosofis.}

Konsep jadal sebagai sebuah ilmu yang dipelajari dan diterapkan, bersumber pada filsafat Yunani. Menurut Al-Syarqānī, jadal sebagai sebuah ilmu diawali oleh paham dialektika yang dicetuskan oleh Heraklitos, kemudian dikembangkan oleh Sokrates, Plato, dan Aristoteles dengan nama ilmu logika. Pemikiran para filosof Yunani ini kemudian memengaruhi pemikiran serta memberikan inspirasi bagi umat Islam untuk menyusun ilmu Jadal yang lebih sesuai dengan ajaran Islam. Al-Qur'an sebagaimana diketahui bukan buku logika atau mantiq yang menguraikan cara-cara berdebat, dan bukan pula buku ilmiah yang memuat buku teori ilmu pengetahuan. Al-Qur'an merupakan kitab hidayah yang penuh oleh petunjuk langsung dari pencipta manusia dan alam semesta, yakni Allah Swt. ${ }^{16}$

Mannā’ Al-Qaththān mengungkapkan perpektifnya bahwa Al-Qur'an tidak menempuh metode yang dipegang teguh para Ahli Kalam atau para teolog yang memerlukan adanya muqaddimah (premis) dan nātijah (konklusi) seperti dengan cara beristidlāl dengan sesuatu yang bersifat kullìy (universal) atas yang juz'̄i (partial) atau sebaliknya. Akan tetapi Al-Qur'an banyak mengemukakan dalil dan bukti yang kuat serta jelas yang dapat dimengerti kalangan awam dan ahli sehingga mampu mematahkan setiap kerancuan dengan perlawanan dalam tata bahasa yang konkret, seperti menggunakan majas, kinayat, tasybih, matsal yang indah, dan tidak memerlukan pemerasan akal. ${ }^{17}$

Urgensi dari Jadal dalam Al-Qur'an adalah untuk membantah argumen-argumen orang-orang kafir dan musyrik. ${ }^{18}$ Menurut Manna' al-Qathan dalam bukunya "Mabahits fii Ulumi al-Qur'an", beliau menyebutkan landasan berpikir pada pembagian argumentasi dalam dua bentuk, ${ }^{19}$ yaitu : Penyebutan Alam semesta untuk memperkuat dalil-dalil yang mengarah kepada akidah yang benar dalam kepercayaan, iman kepada Allah Swt, Malaikatnya, Kitab-kitab Suci, Rasul-rasulnya, dan Hari Akhir.Contoh firman Allah Swt

\footnotetext{
${ }^{15}$ Jalaluddin Al-Suyuthi. Samudera 'Ulūmu al-Qur'ān.

${ }_{16}$ Prof. Dr. Nashruddin B.Wawasan Baru Ilmu Tafsir, 2011, 24.

${ }^{17}$ Manna' Khalil al-Qaththan Mabdhitsfi Uluum al-Qur'an, (Beirut: Mansyurat at-Ashr, 1977), 299.

${ }^{18}$ Manna' Khalil al-Qaththan, Mabahitsfi UIum al-Qur'an, 301.

${ }^{19}$ Manna' Khalil al-Qaththan Mabdhitsfi uluum al-Qur'an, 302.
} 
dalam Surat Al-Baqarah ayat 21-22 ; Menolak argumen-argumen yang salah dari para penyeleweng; Menyebutkan orang yang diajak berbicara itu dengan kata-kata pertanyaan, sehingga terbebas dari permusuhan dan terselamatkan dari permainan akal, sehingga mereka mengakui kesalahan yang mereka perbuat. Sebagaimana Allah Swt berfrman dalam Surat At-Tur ayat 35.

\section{Pendekatan Dialektika Komunikasi}

Di AS saja McLuhan melalui karyanya Democracy in Mass Media (1990) menyebut debat menjadi bagian perilaku komunikasi privat dan publik sebagai implikasi dari "kebebasan berbicara" yang tidak menghendaki intervensi dan kontrol dari pihak mana pun dalam mengemukaan pandangan dan aspirasi. ${ }^{20}$ Dalam berbagai referensi teori dan praktik komunikasi, satu pun tidak dijumpai teori debat. Semua teori, perspektif, pendekatan, paradigma, model, konsep, dan metode komunikasi mengarah pada bagaimana manusia dapat melakukan komunikasi yang penuh makna, negosiatif, konformis, dan saling membahagiakan kedua belah pihak. Begitu pula filsuf Jerman Habermas yang membidani teori kritis dengan salah satu variannya communicative action. Suatu teori yang lahir dari pemikiran waras dan cerdas tentang betapa pentingnya manusia yang mengaku berdemokrasi untuk dapat saling bertindak komunikatif secara sinergis, harmonis, dan dialektis. ${ }^{21}$

Begitu pula konsep dialectics of enlightment yang juga ditelurkan filsuf Jerman, Adorno dan Horkheimer, menghendaki manusia untuk selalu menyatukan pemikiran secara rasional dan tindakan melalui bingkai dialogis agar manusia tercerahkan. ${ }^{22}$

Dalam konsep dialektika komunikasi dalam debat (jadal) yang muncul pada diri manusia, Habermas mengungkapkan terjadi karena tindakan komunikatif manusia memiliki batasan dan tujuan dalam tindakannya. Dorongan subjektivitas individu merupakan hal yang rasional yang menentukan tindakan non-komunikatif maupun komunikatif. ${ }^{23}$

Pandangan Pierre Bourdieu (1977) dalam persoalan dialektika komunikasi menegaskan akan selalu menjadi pengalaman manusia yang muncul akibat adanya konstruksi realitas (doxa). Pandangan (doxa) ini melekat pada semua masyarakat sebagai kebiasaan dalam kehidupan sosial - keyakinan ortodoks maupun heterodoks yang memahami kesadaran adanya perbedaan pandangan dan keyakinan dalam diri seseorang. Tindakan seperti debat disebut Habermas sebagai tindakan normatif, sedangkan Bordieu menyebutnya dengan doxa, terjadi karena adanya subjektivitas dari anggota masyarakat. Habermas menyebutnya sebagai tindakan rasional instrumental, maka Bourdieu menyebutnya dengan keyakinan ortodoks dan heterodoks. Meski terdapat perbedaan secara terminologis, namun kedua filuf modern ini sama-sama meyakini adanya peran dari setiap subjek komunikasi, meski dalam bersifat antagonis sekalipun. Intinya, dalam debat setiap individu dapat saling menilai diri satu sama lain. Ini yang dimaksud dengan

\footnotetext{
${ }^{20}$ Marshal McLuhan, Democracy in Mass Media, (Toronto of University Press, 1990)

${ }^{21}$ Jürgen Habermas. The Theory Of Communicative Action Volume One: Reason And The Rationalization Of Society. Terj. Thomas McCarthy. (Boston: Beacon Press. Hill, Anne, Watson, James, et.al, 1984)

${ }^{22}$ Stephen W.Littlejohn, Theories of Human Communication, Ninth Edition, (USA : SAGE, 2010)

${ }^{23}$ Jürgen Habermas. The Theory Of Communicative Action Volume One: Reason And The Rationalization Of Society. (T1984).
} 
tindakan komunikatif sebagai akibat dari adanya stimulus yang kemudian dipersepsikan sebagai identitas diri pada masing-masing individu. ${ }^{24}$

\section{Konsep Jadal (Debat) dalam Al-Qur'an}

Adapun secara konsep Jadal dengan metode Al-Qur'an memiliki pendekatan yang dapat dijelaskan sebagai berikut :

1. Secara persuasif membungkam lawan bicara (komunikan) dengan mengajukan pertanyaan tentang hal-hal yang telah diakui dan diterima akal (logika), agar ia mengakui apa yang tadinya diingkari. Seperti penggunaan dalil dengan makhluk untuk menetapkan adanya Khāliq.

2. Mengambil dalil dengan mabda' (asal mula kejadian) untuk menetapkan $m a^{\prime} \bar{a} d$ (hari kebangkitan).

3. Membatalkan pendapat lawan dengan membuktikan kebenaran kebalikannya, seperti bantahan terhadap pendirian orang Yahudi.

4. Menghimpun dan memerinci beberapa sifat dengan memberi keterangan bahwa sifat-sifat bukanlah 'illah (alasan hukum).

5. Membungkam lawan dan mematahkan hujjah-nya dengan menjelaskan bahwa pendapat yang mereka kemukakan adalah tidak masuk akal dan tidak dapat diakui. ${ }^{25}$

Didalam kitab Al-Itqon fii Ulumil Qur'an, Imam Syuyuti menyebutkan beberapa hal yang termasuk dalam bentuk Jadal, ${ }^{26}$ di antaranya:

1. Al-Isyjal yaitu meletakkan kata yang menunjuk kepada lawan bicara dan juga apa yang dibicarakan. Contohnya dalam firman Allah dalam Surat Ali Imron ayat194.

2. Al-Intiqol yaitu memindahkan argumen yang dijadikan dalil ke arah argumen yang tidak dapat diikuti sehingga di dalam perdebatan kadang argumen tidak dimengerti maksudnya oleh lawan. Contoh dalam surat Al-Baqoroh ayat 258, memaknai istilah menghidupkan dengan membebaskannya di sinilah kekeliruan tersebut sehingga Allah Swt mengubah argumen dengan yang lainnya yaitu menerbitkan matahari dari Barat

3. Munaqodhoh, yaitu menggantungkan sesuatu dengan hal yang mustahil, yang mengisyaratkan kemungkinan terjadi. Contoh dalam Al-Qur'an Surat Al-A'raf ayat 40.

4. Artinya: "Dan mereka tidak akan masuk ke dalam surga hingga unta masuk ke lubang jarum".

Metode Jadal Al-Qur'an menurut Muh. Sabiq Basyiri Abdul Mu'thi memiliki dua tipe, yaitu :27Metode yang mengandalkan kekuatan komunikasi (kemampuan verbal dan bahasa) dapat diuraikan sebagai berikut:

\footnotetext{
24 Pierre Bourdieu. Outline Of A Theory Of Practice. Terj. Richard Nice. (Great Britain: Cambridge University Press. 1977), 164

${ }^{25}$ Mana'ul Quthan,Pembahasan Ilmu Al-Qur'an, (Jakarta : Rineka Cipta.1995), 132.

${ }^{26}$ Jalaluddin As-Syuyuti', Al-Itqon Fii Uluml al-Qur'an, (1979 M), 269.

27 Teuku Muhammad Hasbi Al-Shiddiqiey. Ilmu-Ilmu Al-Qur'an (Edisi Baru). (Semarang. Pustaka Rizqi Putra. 2010), 36.
} 
a. Al-Istidlal al-Hamli, yaitu penyusunan argumentasi dengan mengawinkan premis-premis tertentu. Metode ini sering dipakai oleh para filsuf dan pakar teolog. Kemustahilan bertemunya dua hal pada ruang dan waktu yang sama, misalnya pada Surat Al An'am ayat 76-80, Subjek: Ibrahim-Kaumnya, Topik: Tuhan Alam Semesta.

b. Al-Istidlal al-Istisna'iy, yaitu membangun sebuah argumentasi dengan membuat pengandaian mengenai sesuatu (objek yang dibahas). Maksud dari metode ini, yaitu mustadil menyandarkan keabsahan sebuah pernyatan (malzum) pada sesuatu yang inhern di dalamnya (lazim). Dalam artian bila lazim salah (tidak ada), maka demikian pula yang terjadi pada malzum. Bila metode ini dipakai untuk menghadapi orang yang menyembah matahari, maka akan ada untaian premis: "Bila matahari adalah Tuhan (malzum), maka niscaya ia tidak akan lenyap di malam hari." Tujuan penggunaan metode ini adalah untuk meniadakan lazim dari suatu pernyataan. Dengan kata lain, mementahkan argumen lawan dengan menyebutkan kemustahilannya dikarenakan tidak tercukupinya syarat untuk menuju kepada maksud argumen tersebut. Contoh ayat: Surat Al Baqarah ayat 21-24, Subjek: AllahKaum Kafir, Topik: Ibadah kepada Allah.

c. Qiyas al-Dilalah, membangun argumentasi dengan menggunakan suatu ungkapan yang dapat menunjukkan (menjadi dilalah) kepada apa yang dimaksud. Contoh ungkapan "cairan" ini tidak dapat digunakan untuk menghilangkan hadas yang dimaksudkan untuk menyebut bahwa benda tersebut tidak dapat menghilangkan najis. Contoh Surat ke-14 ayat 9-14, Subjek: Para rasul-Kaumnya, Topik: Wujud Tuhan.

d. Al-Istifar, yaitu metode sanggahan dalam Jadal al-Qur'an. Metode ini dilakukan dengan meminta pihak lawan untuk menjelaskan kata-kata yang masih ambigu dari argumentasi yang telah ia sampaikan. Contoh ayat: Surat ke-20 ayat 4755, Subjek: Fir'aun, Musa dan Harun, Topik: Kenabian Musa dan Harun.

e. Fasad al-Wad'i wa al-I'tibar, adalah menyanggah dengan menunjukkan kesalahan mustadil dalam pengambilan landasan argumentasi. Contoh ayat: Surat Al Baqarah ayat 84-85, Subjek: Allah-Ahli Kitab, Topik: Larangan membunuh dan lain sebagainya.

f. Al-Man', secara literal berarti menolak atau mencegah. Metode ini dipakai untuk menyatakan keberatan hati mu'tarid menerima pernyataan mustadil, baik disertai dengan pendapat $m u^{\prime}$ tarid atau tidak. Dalam praktiknya, metode ini hampir sama dengan makna i'tirad, karena itu, dalam banyak kesempatan metode ini disertai dengan metode jadal lainnya. Contoh ayat: Surat Al Baqarah ayat 11-13, Subjek: Mukminun-Munafiqun, Topik: Ajakan untuk beriman.

g. Al-Taqsim, adalah metode untuk menanggapi pernyataan seseorang. Kerja metode ini dijalankan dengan menimbulkan keraguan di benak mustadil, yaitu dengan menyebutkan rincian kemungkinan pemaknaan lain dari sebuah kata yang dinyatakan mustadil.Contoh ayat: Surat Al Baqarah ayat 94, Subjek: Allah-Kaum Yahudi, Topik: Pengakuan Yahudi bahwa Mereka adalah Putera Tuhan.

h. Al-Qad, adalah metode menyanggah dengan jalan mencela pernyataan mustadil, dengan alasan bahwa pernyataan itu dapat menimbulkan sebuah sesuatu yang justru jauh dari kemaslahatan (kebaikan). Contoh ayat: Surat Al Baqarah ayat 30-33, Subjek: Allah-Malaikat, Topik: Penunjukan Adam sebagai Khalifah. 
i. Qiyas al-I'adah, metode ini untuk menghadapi mereka yang tidak percaya kepada adanya pencipta alam semesta serta mengingkari adanya hari kebangkitan dan kehidupan setelah mati. Metode ini dijalankan dengan menggambarkan kekuasaan Allah untuk menghidupkan orang mati, menciptakan langit di bumi, mengeluarkan api dari pohon dan lain sebagainya. Contoh ayat: Surat Al An'am ayat 1-2, Subjek: Allah-Kaum Kafir, Topik: Pencipta Alam Semesta.

j. Al-Mu'aradah, adalah metode Jadal dengan menunjukkan pertentangan (kontradiksi internal) dalam pernyataan lawan (mustadil). Metode ini juga bisa dilakukan dengan mengatakan bahwa pernyataan mustadil justru merugikan dirinya sendiri. Maksud dari ayat di dalamnya bahwa ajaran tersebut adalah ajaran terdahulu. Contoh Surat Al Baqarah ayat 135, Subjek: Allah-Kaum Yahudi dan Nasrani, Topik: Anggapan Kaum Yahudi dan Nasrani tentang Hidayah.

k. Al-Farqu, metode ini dipakai bila seorang pendebat menghadapi pernyataan yang menyamakan dua hal yang berbeda. Jadi fungsinya adalah membatalkan analogi dua hal berbeda dengan menyebutkan keunikan jawaban. Metode ini juga bisa dijadikan jawaban bagi pertanyaan yang menggunakan metode al-Istifar. Contoh ayat: Surat Al Baqarah ayat 258, Subjek: Ibrahim-Namrud, Topik: Tuhan Alam Semesta.

1. Al-Qaul bi al-Mujab, metode ini digunakan untuk menjawab pernyataan yang memiliki landasan yang tidak tepat. Metode ini ialah dengan menerima sebagian pernyataan mustadil dan meluruskan jalan pikirannya yang tidak tepat tersebut. Contoh ayat: Surat Nuh ayat 25-34, Subjek: Nuh-Kaumnya, Topik: Seruan kepada Tauhid.

m. Al-Sabru wa al-Taqsim, metode ini adalah metode sanggahan dengan mengajukan pernyataan mengenai alasan pernyataan lawan. Contoh ayat: Surat Al An'am ayat 143-144, Subjek: Allah-Kaum Kafir, Topik: Haramnya binatang.

\section{Metodologi}

Artikel ini penyusunannya didasarkan pada studi kualitatif dengan jenis metode yaitu studi literatur dengan analisis tematik pada beberapa literatur dan referensi yang relevan dengan tema penulisan.

\section{Analisis dan Pembahasan}

\section{Analisis}

Pendekatan atau konsep Jadal dalam Al-Qur'an dalam perspektif historis, filosofis, dan Dialektika Komunikasi melalui studi literatur ini pada konteks atau realitas peristiwa debat, seperti Debat Capres 2019 dengan pelaku Jokowi-Ma'ruf Amin dengan PrabowoSandiaga Uno di media mainstream dan media sosial di tengah pluralitas keagamaan di bumi Indonesia ini.

Pada dimensi subjek (Jokowi-Ma'ruf Amin dengan Prabowo-Sandiaga Uno) sebagai pihak yang melakukan tanggapan atau sanggahan yang tajam dan saling serang, yang ditingkahi dengan teriakan, seruan, canda, dan bahkan hujatan dari kedua pendukung dalam Al-Qur'an menunjukan karakterirtik debat (jadal) seperti : Hanya mengandalkan logika atau nalar-nalar politik, seperti berusaha membungkam lawan bicara (komunikan) dengan mengajukan pertanyaan tentang angka-anagka, hasil yang akan dan telah dicapai secara ekonomi dan politis, tanpa penggunaan dalil untuk menyertakan keberadaan Sang Pencipta; salin membantah pendapat lawan dengan bukti-bukti yang relatif kebenarannya 
seperti bagaimana cara memberantas korupsi, lingkungan hidup, pertahanan - keamanan, dan penegakan hukum.

Perdebatan Capres 2019 yang disaksikan ratusan juta pasag mata di Indonesia memang penting untuk disaksika karena menentukan bangsa ini ke depannya, namun setidaknya kaidah-kaidah debat perlu dipegang kuat sesuai Al-Qur'an.

Secara Dialektika Komunikasi, ketika Prabowo yang berpenampilan bersahaja dan tegas karena memang tegas, dan ada orang tegas karena mencoba untuk terlihat tegas sehingga dipersepsikan tegas oleh orang lain. Dialektika dan dialog bersifat pararel, di mana keduanya mampu lebih memperdalam pemahaman seseorang mengenai subjek dengan mempertimbangkannya dari berbagai sisi. Jokowi misalnya, mungkin mampu menguasai dan menjawab permasalahan tentang korupsi seperti apa yang ditanyakan panelis pada acara Debat Pilpres 2019. Namun, setelah masalah korupsi tersebut dapat diidentifikasi dalam sebuah dialog sekalipun, Plato menyatakan itu sama sekali tidak menjamin bahwa diskusi akan berakhir dengan kesepakatan, apalagi dengan kesimpulan. Apalagi sebuah debat. Karena, dialog dan komunikasi sudah pasti ditujukan pada terciptanya konsensus. Khusus, masalah debat Capres 2019 ini, adanya "tindakan komunikatif" antara Jokowi-Prabowo tentu sangat berpengaruh pada hubungan yang terjalin di antara mereka. Jelasnya, semua bentuk relasi manusia melibatkan komunikasi di dalamnya, termasuk relasi manusia dengan Allah Swt. Harmoni adalah ruhnya. Selanjutnya, dalam debat Capres 2019, jokowi atau Prabowo yang benar atau salah adalah tergantung pada tindak komunikatif mereka sendiri. Karena, wacana dialektika sendiri tidak bertujuan untuk mencari pemenang secara pribadi, tapi pada kebenaran antarpribadi.

\section{Pembahasan}

Pada artikel mengenai Dialektikan Komunikasi Debat Capres 2019 dalam Perspektif Al-Qur'an ini secara khusus menghasilkan pembahasan tentang pengertian dan landasan berpikir Jadal sebagai debat, dialog antara Jokowi dan Prabowo sebagai pihak dengan kehendak untuk menang melalui alasan dan argumentasi mereka. Namun, secara dialektis kedua Capres ini hanya bersandar pada alasan-alasan logika - pengungkapan bukti-bukti kuantitatif yang rasional-empiris dengan tujuan untuk mengalahkan pihak lawan dan para penantangnya sekaligus terlihat hanya untuk menegakkan citra dan visi misi kelompok masing-masing. Kurang memberikan pembuktian atas kebenaran yang dapat diterima oleh nurani masyarakat Indonesia. Meski sikap pengendalian diri dan penggunaan verbal yang tetap terjaga baik.

Sebagai suatu ilmu, debat (Jadal) didasarkan pada perspektif historis dan perspektif filosofis. Secara perspektif historis, seperti yang diriwayatkan dalam Al-Qur'an, khususnya Surat Al Mujadalah ayat 58 sebagai awal mula munculnya istilah Jadal melalui kisah Khaulah binti Tsa'labah. Pemahaman debat dari kedua Capres tampaknya lebih mengacu pada adu argumen, adu kekuatan, dan adu citra yang seharusnaya lebih menjunjung tinggi prinsip-prinsip kebenaran yang hakiki dan abadi. Sedangkan dalam perspektif filosofis, Jadal merupakan pendekatan yang bukan berbasis premis mayor minor tapi berdasarkan muqadidimah dan natijjah nya. Al-Qur'an adalah sumber logika yang hakiki dibanding para pendapat pakar politik, ekonom, sosiolog, budayawan, bahkan teolog. Karena itu, sesungguhnya Al-Qur'an memuat argumen-argumen rasional dan metode-metode yang mudah dipahami melalui penjelasan ayat-ayatnya. Jadi, Jadal atau bukan debat bebas yang dilakukan Capres 2019 yang tanpa didasarkan Al-Qur'an seperti yang sudah disaksikan 
rakyat Indonesia. Jadal dapat, ada yang mamduh dan ada pula yang madmum, dengan landasan dan contohnya masing-masing di dalam Al-Qur'an. Jadal dalam Al-Qur'an dilihat dari pelaku (subjek) dan hal yang dipersoalkan, menyangkut space and time yang sangat luas. Pernah terjadi antara Allah dengan Malaikat, dengan para Nabi, Nabi dengan kaumnya atau penentangnya, orang perorang di kalangan Bani Adam, dari dulu sampai dengan masa Al-Qur'an diturunkan. Bahkan model-model jadal yang tergambar dalam AlQur'an, di antaranya masih belangsung sampai sekarang. Demikian pula hal yang dipersoalkan dalam Jadal hampir menyangkut keseluruhan dimensi kehidupan manusia, bahkan setelah kehidupan yang sekarang.

Tujuan dari penulisan tentang Debat Capres 2019 relevansi dengan perspektif Jadal al-Qur'an antara lain untuk menjadi pijakan para pelaku debat untuk selalu menetapkan aqidah tentang wujud dan wahdaniyah Allah serta petunjuk dan syari'ah bagi yang melakukan debat. Menjelaskan permasalahan secara argumentatif bagi kedua Capres 2019 dan para pendukungnya juga umat Islam yang memang secara serius ingin mendapat kejelasan dari permasalahan yang dihadapi bangsa ini. Selain itu, untuk mematahkan opini negatif dan hujatan para penentang (lawan politik) dengan pembuktian yang lebih kuat dan akurat, dengan berbagai perspektif dan metode seperti Dialektika Komunikasi yang cenderung lebih dialogis dan berpigak pada konsensus dilandasi pemahaman jadal dalam Al-Qur'an seperti : al Ta'rifat, al Istifham al Taqriri, al Tajzi'at, Qiyas al Khatf, at tamsil dan al Muqabalat untuk lebih memahaminya dapat membantu menjelaskan kandungan kebenarannya.

\section{Kesimpulan}

Melalui pendekatan Dialektika Komunikasi pada makna Debat Capres 2019 melaui konsep Jadal al-Qur'an, ternyata lebih memudahkan dalam memverifikasi dan menjelaskan, baik perbedaan maupun persamaannya. Debat yang dilakukan Capres (Jokowi-Ma'ruf Amin) dengan Prabowo- Sandiaga Uno ternyata hanya konsep yang dikonstruksi manusia karena munculnya intersubjektivitas di antar dua pihak yang berkomunikasi atau berinteraksi mengenai persoalan tertentu, dalam hal ini politik dan kebangsaan. Sedangkan, Jadal dalam Al-Quran merupakan wahyu yang disampaikan pada Rasul-rasul-Nya dalam menjalankan argumentasi dan menghadapi pembangkangan kaum Yahudi dan Nasrani yang selalu menentang dakwah-dakwah Rasul dan Nabin-Nya di muka bumi. Karena itu, pengertian atau konsep Jadal jauh memiliki memiliki landasan historis dan filosofis yang sangat, yang berimplikasi pada dampak kuat bagi kemaslahatan umat manusia. Jadal, sebagai konsep yang sangat lengkap dalam memecahkan persoalan manusia, disamping manusia sebagai makhluk yang thabi'iyah, juga rasional dan emosional sekaligus. Sehingga dengan Jadal manusia akan lebih mudah dapat diarahkan untuk mencapai tujuan komunikasi yang dialektis dan dialogis, lebih mencerdaskan kehidupan bangsa dan mengembangkan manusia seutuhnya, membina manusia yang beriman dan bertaqwa serta berakhlak mulia.

\section{Daftar Pustaka}

Al Isfahani, Al-Raghib, Mu'jam Mufradit al-Fadz al-Qur'an, Beirut: Dar al-Fikr, t.th Al-Qaththan, Manna' Khalil, Mabdhitsfi uluum al-Qur'an, Beirut: Mansyurat at-Ashr, 1977 Al-Alamaiy, Zahir 'Awad,Manahij al-Jadal fi al-qur'an al-Karim, t.tp.,t.th 
Anam, Ahmad Khoirul, Rumba Triana, Aceng Zakaria, Debat dalam Perpektif Al-Qur'an : Studi Tematik Ayat-ayat tentang Debat, ProsA IAT: Prosiding Al Hidayah Ilmu AlQuran dan Tafsir, Vol.1, No.1, 2019

Al-Shiddikiey, Teuku Muhammad Hasbi,. 2010. Ilmu-Ilmu Al-Qur'an (Edisi Baru). Semarang. Pustaka Rizqi Putra.

As-Syuyuti, Jalaluddin Al-Itqon Fii Uluml al-Qur'an, Dar al-fikr Beirut Beirut, 1979

B, Nashruddin.Wawasan Baru Ilmu Tafsir, Yogyakarta: Pustaka Pelajar, 2011.

Bourdieu, Pierre. Outline Of A Theory Of Practice. Trans. Richard Nice. Great Britain: Cambridge University Press. 1977, h.164

Departemen Pendidikan dan Kebudayaan, Kamus Besar Bahasa Indonesia,edisi kedua Cet.III

Damayanti, Novita, Gaya Komunikasi Jokowi pada Debat Politik Pilpres 2019, Wacana Jurnal Ilmiah Ilmu Komunikasi, Vol. 14, No . 2 , 2015, h.155

Habermas, Jürgen. The Theory Of Communicative Action Volume One: Reason And The Rationalization Of Society. Trans. Thomas McCarthy. Boston: Beacon Press. Hill, Anne, Watson, James, et.al, 1984

Littlejohn, Stephen W, Theories of Human Communication, Ninth Edition, USA : SAGE, 2010

McLeod dan Chafee. Handbook of Theories Communication. London : Routledge. 1972

Mutiara,Ni Luh Arisma., El Chris Natalia, Pemaknaaan Pesan Komunikasi Publik dalam Debat Calon Presiden 2019, Jurnal InterAct, Vol. 8, No. 2 , 2019

M. Yusuf, Khadar . Studi Al-Qur'an. Jakarta: 2009

McLuhan, Marshal Herbert, Democracy in Mass Media, Toronto of University Press, 1990

McLeod dan Chafee . Handbook of Theories Communication. London : Routledge. 1972

Quthan, Man'ul, .Pembahasan Ilmu Al- Qur'an.Jakarta : Rineka Cipta.1995

Ummah, Sun Choirol, Dialektika Agama dan negara dalam Karya Jurgen Habermas, Jurnal Humanika, Vol. 16, Nomor 1, September 2016 